\title{
Restoration proposal for correction of pathologies in concrete bridge - case study in the city of Teófilo Otoni, Brazil
}

\author{
Proposta de restauração para correção de patologias em ponte de concreto - estudo de caso na \\ cidade de Teófilo Otoni, Brasil \\ Propuesta de restauración para corrección de patologías en puente de hormigón - estudio de caso
} en la ciudad de Teófilo Otoni, Brasil

Received: 05/04/2021 | Reviewed: 05/09/2021 | Accept: 05/11/2021 | Published: 05/21/2021

Heberson Teixeira da Silva

ORCID: https://orcid.org/0000-0001-9163-6984 Federal University of the Jequitinhonha and Mucuri Valleys, Brazil E-mail: hebersonteixeirasilva@gmail.com Luély Souza Guimarães

ORCID: https://orcid.org/0000-0001-8817-7326 Federal University of the Jequitinhonha and Mucuri Valleys, Brazil E-mail: luelyguimaraes@hotmail.com

Dilceu Silveira Tolentino Júnior

ORCID: https://orcid.org/0000-0003-2435-7576 Federal University of the Jequitinhonha and Mucuri Valleys, Brazil

E-mail: dilceujunior@bol.com.br

Arthur Souza Campos

ORCID: https://orcid.org/0000-0003-4773-0345 Federal University of the Jequitinhonha and Mucuri Valleys, Brazil E-mail: aarthurcampos@hotmail.com

André Lopes Frisso

ORCID: https://orcid.org/0000-0003-2399-1903 Federal University of the Jequitinhonha and Mucuri Valleys, Brazil E-mail: frissoandre@gmail.com

Alexandre Sylvio Vieira da Costa ORCID: https://orcid.org/0000-0001-7251-7816 Federal University of the Jequitinhonha and Mucuri Valleys, Brazil E-mail: alexandre.costa@ufvjm.edu.br

Stênio Cavalier Cabral

ORCID: https://orcid.org/0000-0001-5241-9776 Federal University of the Jequitinhonha and Mucuri Valleys, Brazil E-mail: stenio.cavalier@ufvjm.edu.br

Lucas Ferreira Freitas

ORCID: https://orcid.org/0000-0001-6826-6970 Federal University of the Jequitinhonha and Mucuri Valleys, Brazil E-mail: lucas.freitas@ufvjm.edu.br

\begin{abstract}
The bridges are important structures for the development of cities, they allow access to places previously isolated due to geological non-conformities or by obstacles such as rivers and valleys, facilitating the access of products and the movement of vehicles and people. The conservation, maintenance, and recovery of these structures are essential for their proper functioning and the safety of their users. However, it is not uncommon to find bridges out of their ideal state of use, presenting a lot of pathologies, and, for these pathologies to be repaired, it can be used various recovery techniques and kinds of treatments. This study aims to analyze the pathologies and their possible options of restorations on the bridge located at João Lopes da Silva Street, Manoel Pimenta neighborhood, in the city of Teófilo Otoni - Brazil. The identification and classification of the pathologies and nonconformities found in the artwork have been carried out. The analyzed bridge needs maintenance so that its functionality is not affected, requiring appropriated recovery techniques such as the use of epoxy resin in cracks, removal of corrosion from reinforcement and application of anticorrosive paints, scarification of concrete in the area in which there is disaggregation, and concreting through forms and drainage devices compatible with local needs, providing a longer life span and avoiding inconvenience for users.
\end{abstract}

Keywords: Bridges; Pathologies; Restoration. 


\section{Resumo}

As pontes são estruturas importantes para o desenvolvimento das cidades, pois permitem o acesso a locais antes isolados por inconformidades geológicas ou por obstáculos como rios e vales, facilitando o acesso de produtos e a circulação de veículos e pessoas. A conservação, manutenção e recuperação dessas estruturas são essenciais para o seu bom funcionamento e a segurança de seus usuários. Porém, não é incomum encontrar pontes fora do seu estado ideal de uso, apresentando uma série de patologias e, para que essas patologias sejam reparadas, podem ser utilizadas várias técnicas de recuperação e tipos de tratamentos. Este estudo tem como objetivo analisar as patologias e suas possíveis opções de restaurações na ponte localizada na rua João Lopes da Silva, bairro Manoel Pimenta, no município de Teófilo Otoni - Brasil. Foi realizada a identificação e classificação das patologias e não conformidades encontradas na obra de arte. A ponte analisada necessita de manutenção para que sua funcionalidade não seja afetada, exigindo técnicas de recuperação adequadas como o uso de resina epóxi em fissuras, remoção de corrosão de armaduras e aplicação de tintas anticorrosivas, escarificação de concreto na área em que há desagregação, e concretagem por fôrmas e drenos compatíveis com as necessidades locais, proporcionando maior vida útil e evitando transtornos aos usuários.

Palavras-chave: Pontes; Patologias; Restauração.

\section{Resumen}

Los puentes son estructuras importantes para el desarrollo de las ciudades, permiten el acceso a lugares previamente aislados por no conformidades geológicas o por obstáculos como ríos y valles, facilitando el acceso de productos y el movimiento de vehículos y personas. La conservación, mantenimiento y recuperación de estas estructuras son fundamentales para su correcto funcionamiento y la seguridad de sus usuarios. Sin embargo, no es raro encontrar puentes fuera de su estado ideal de uso, presentando una gran cantidad de patologías, y para que estas patologías sean reparadas se pueden utilizar diversas técnicas de recuperación y tipos de tratamientos. Este estudio tiene como objetivo analizar las patologías y sus posibles opciones de restauración en el puente ubicado en la calle João Lopes da Silva, barrio Manoel Pimenta, en la ciudad de Teófilo Otoni - Brasil. Se ha realizado la identificación y clasificación de las patologías y no conformidades encontradas en la obra de arte. El puente analizado necesita mantenimiento para que su funcionalidad no se vea afectada, requiriendo técnicas de recuperación adecuadas como el uso de resina epoxi en grietas, remoción de corrosión de armaduras y aplicación de pinturas anticorrosivas, escarificación del concreto en la zona en la que hay desagregación, y hormigonado mediante encofrados y dispositivos de drenaje compatibles con las necesidades locales, proporcionando una mayor vida útil y evitando molestias a los usuarios.

Palabras clave: Puentes; Patologías; Restauración.

\section{Introduction}

According to Marchetti (2018), a bridge designed to allow the crossing of obstacles such as rivers, sea arms, deep valleys, other roads, or the continuity of any kind of communication is called a bridge. Such structures can be made of wood, masonry, reinforced concrete, prestressed concrete, or steel, and are subject to the actions of several pathologies, caused mainly by failures of constructive execution, continuous use of the structure, doubtful maintenance, and climatic factors. The maintenance of reinforced concrete bridges is neglected, eventually providing the emergence and aggravation of pathologies that could be avoided if there was adequate monitoring.

In Brazil, the lack of maintenance of bridges and viaducts is one of the biggest problems faced by the road system. Thus, planning, designing, and carrying out the maintenance of works of art in an appropriate manner are major challenges faced in Civil Engineering. Thus, each stage of construction of this type of work challenges the professionals involved, forcing them to seek appropriate solutions for each particularity found (Vitório, 2006).

For the social and economic objectives they fulfill, bridges are of great importance for transport on highway roads. Due to the enormous impacts that can be caused due to the rupture of the structure, the interruption, or the paralysis of its road flow, a periodic maintenance routine becomes necessary so that people and cargo can safely transmit the requested efforts, thus avoiding substantial economic impacts (Milani \& Kripka, 2009).

Most of the pathologies are the result of improper use and lack of proper maintenance. After rigorous analysis to identify the causes of pathological manifestations, the type of treatment that will be applied must be chosen. According to Souza and Ripper (1998), this depends, firstly, on the pathology detected and its stage, which when advanced, it is necessary to 
recover the structure.

Bridge pathologies can be divided into two groups: by intrinsic causes, which are those that originate from materials and structural parts during execution, or by human failures; and for extrinsic causes, which can be understood as the factors that affect the structure from the outside to the inside during its useful life (Souza \& Ripper, 1998). For the following work, we will analyze pathological manifestations of efflorescence, cracking, exposure of the reinforcement, due to insufficient coverage, and its corrosion.

Concrete is a material that has high resistance to compression stresses, but has low tensile strength, being used in large proportions in these works of art. Therefore, it is necessary to associate concrete with a material with high tensile strength, such as steel. Then, the so-called reinforced concrete appears, where the reinforcement bars absorb the tensile stresses and the concrete absorbs the compressive stresses. In addition, the essential characteristic for this association is the bond between the concrete and the reinforcement. There must be real solidarity between both, guaranteeing the durability of the structure and avoiding future pathologies (Bastos \& Miranda, 2017).

In the national scenario, countless bridges deteriorate with the need for structural restorations, which have been neglected for years. Not unlike this scenario, in the municipality of Teófilo Otoni, the same problem occurs, where there are numerous bridges in need of restoration and with different pathologies. Thus, this case study aims to analyze the pathological manifestations of the bridge located at João Lopes da Silva Street, Manoel Pimenta neighborhood, Teófilo Otoni - MG, indicating which repairs should be performed, treating each pathology individually. It is a small and spanned reinforced concrete bridge, with a mixed structure, located on an urban road.

\subsection{General concepts in concrete bridges}

The National Department of Transport Infrastructure (DNIT) defines a bridge as being a structure, including supports, built on a depression or an obstruction, such as water, highway or railroad, which supports a lane for the passage of vehicles and other moving loads, and which has a free span, measured along the axis of the highway, of more than six meters. Viaducts, overpasses, and underpasses are included in this definition (DNIT, 2004).

There are several types of materials that can be used for the construction of a bridge, such as wood, concrete, and steel. For Vasconcelos (2018), because it is a material with easy access, use, and high durability, the most used material in the world is reinforced concrete. In addition, it is possible to design, with the development of technology, a reinforced concrete bridge in minutes using the software.

The Bridge and Viaduct Recovery Manual (DNIT, 2010) points out and describes the main types of pathologies in bridges, which can occur in the superstructure, manifested in paving, in the bridge over two beams or in multiple beams, in reinforced concrete beams, in prestressed concrete beams, coffin structures, slab structures on arched bridges or rigid gantry bridges; they occur in the infrastructure and can be found on the wall pillars or the isolated pillars with connecting crossbars and also in the encounters, these pathologies being the result of infiltrations in the expansion joints, cracks resulting from the irregular laying of the foundations or subsequent cracks of weak reinforcement in the walls. In this context, Helene (1997) states that the pathologies that appear most frequently in concrete structures are cracks and efflorescences.

Cracks, according to Souza and Ripper (1998), are those derived from the wrong design of structural elements or errors at the time of execution. These are the errors that usually result in the appearance of cracks in structures such as flexion, traction, among others.

According to Laner (2001), efflorescence is the result of the leaching of limestone compounds that can, under certain conditions, form salt deposits on the concrete surface. This is the result of poorly densified concrete or poorly executed joints. 
Andrade (1992) states that the concrete covering is a physical barrier that protects the reinforcement and, according to Helene (1992), there are a large number of structures that present corrosion of their reinforcement, due to the lack or loss of the natural protection offered by the concrete covering, that is, insufficient and low-quality protective layer.

There are numerous types of pathologies with disintegration, which is the deterioration of the concrete by separation of its parts, caused by the expansion due to the oxidation or expansion of the reinforcement, by the increase in the volume of concrete, when it absorbs water, and by the insufficient openings of the concrete expansion joints, which generate unforeseen tangential stresses, which may also occur due to structural movements and shocks in the structure). In addition, faults in drainage installations are factors that also influence the degradation of concrete and frames. Thus, they must be avoided so that it does not allow water to accumulate in points, such as beam support meetings, board meetings, the running track, and support devices (Laner, 2001).

For a structure that presents pathology to be placed in an ideal state of use, it is necessary to use restoration techniques. Each type of pathology requires a different type of procedure for its recovery. Therefore, DNIT, through the road bridges and viaducts recovery manual, indicates several techniques to combat different pathologies: cracks and cracks, corrosion removal, concrete replacement, stain removal, among others.

The most traditional method applied in the treatment of cracks in bridges and viaducts without water is the injection of epoxy paint, being, for Helene (1997), a necessary factor to avoid corrosion in the reinforcement. On the other hand, when it comes to efflorescence, conventional protection systems are recommended, such as transparent acrylic varnish with pigmented flexible acrylic paint, as these elements generate great protection against UV rays and rain.).

\section{Methodology}

A case study is a description and analysis, as detailed as possible, of some case that has some particularity that makes it special (Pereira et al., 2018).

The case study in question aims to research and collect data on pathological manifestations on a bridge in the city of Teófilo Otoni, as well as the search for proposals and solutions to solve them.

Observation techniques are very useful to reveal new perspectives on a problem. Qualitative methods are the ones in which the interpretation by the researcher with his opinions about the phenomenon under study is important. Data collection often occurs through interviews with opened questions, making it crucial in situations where there is no solid theoretical basis to guide data collection (Pereira et al., 2018; Ludke, 2013).

Classified as qualitative, the research used in this case study involves the interpretation of the information collected and the attribution of solutions, that are the basis of the qualitative research method. Usual and pertinent situations of structural pathologies were investigated with the available bibliography for comparison of data collected in the work of art under study.

The history of the occurrence of pathologies that were treated in this case study was shared by local residents, who reported recurrences of municipal negligence regarding the maintenance and restoration of the reinforced concrete bridge, which contributed to its pathological evolution and degradation. 
Figure 1. Map of the Brazilian territory identifying the state of Minas Gerais and the municipality of Teófilo Otoni that hosts the studied bridge.

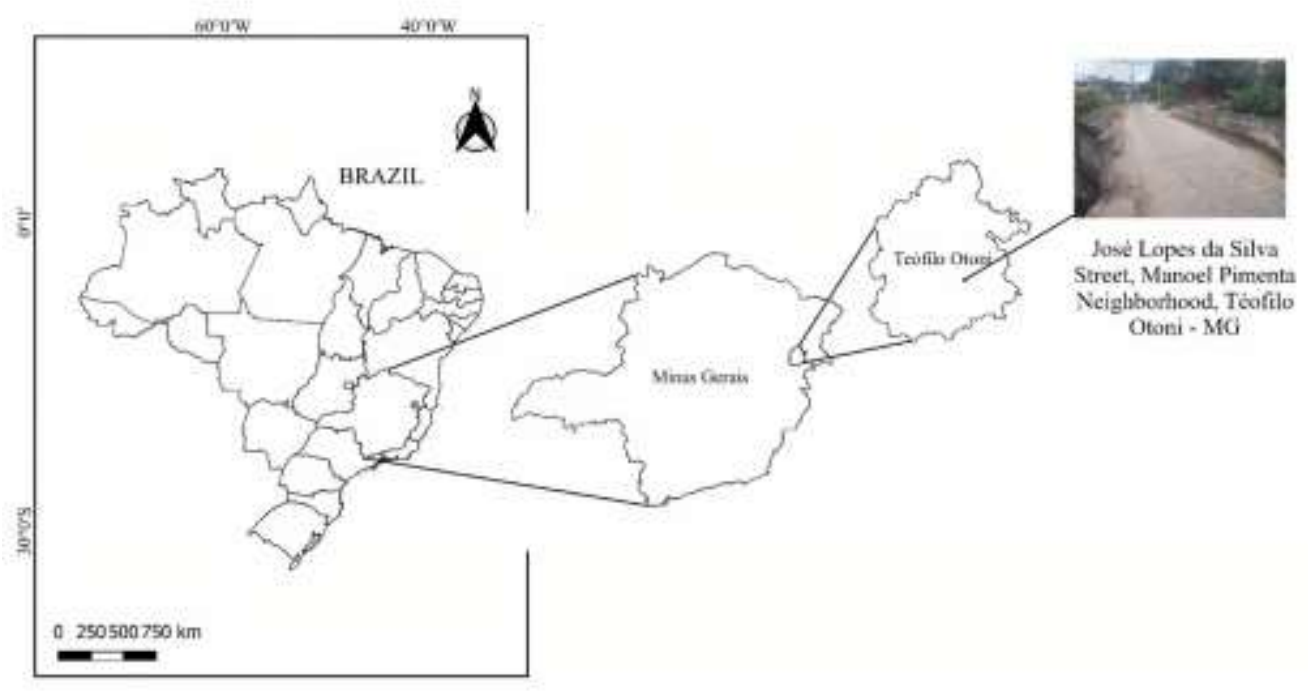

Source: Authors (2021).

The Figure 1, above, shows the details of the location where the studied bridge is located. Note that it is located in the city of Teófilo Otoni, in the state of Minas Gerais, in Brazil. The photos were arranged schematically for better understanding and visualization.

Figure 2. Satellite image of the analyzed bridge.

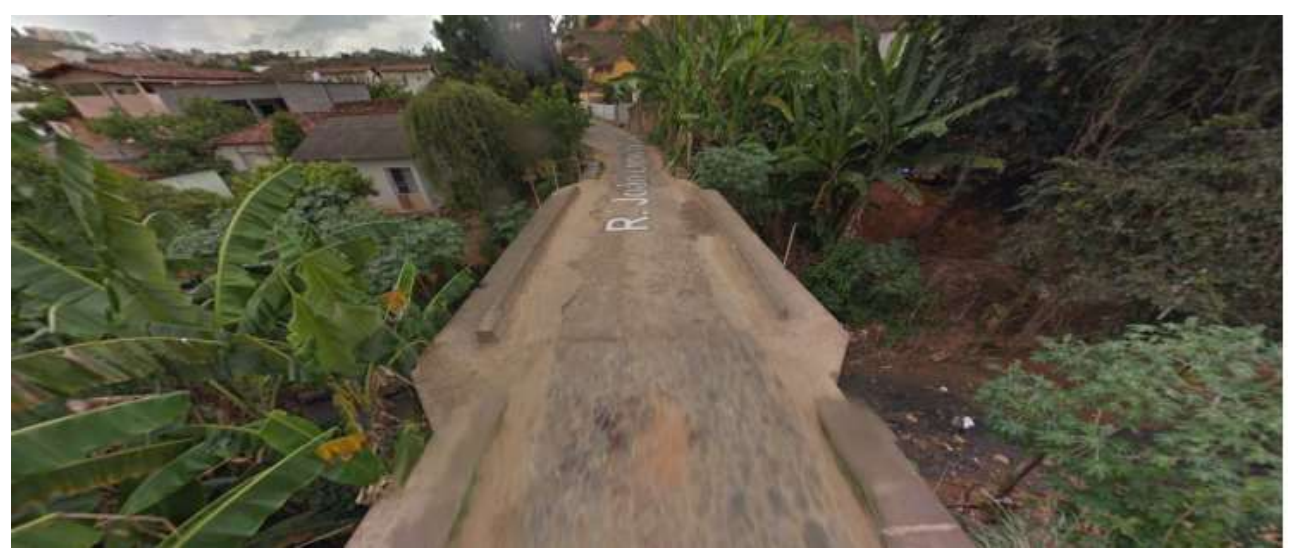

Source: Google maps, adapted (2020).

The Figure 2, above, illustrates, through a satellite image, dated February 2020, the bridge that serves as the object of study. In addition, for a precise location of the bridge (-17.87108332068995, -41.497607676923295), georeferencing was performed, using the SAD69 (South American Datum) geodetic system using a GPS (Global Positioning System).

\subsection{Procedures adopted during study and analysis of results}

The survey of subsidies is the stage in which the essential and sufficient information for the complete understanding of the pathological manifestations is organized. This information is obtained in three ways: site survey; historical survey of the 
problem and structure, and the result of the analyzes. Thus, surveys were carried out on the bridge, where pathological manifestations were identified, such as corrosion in an advanced state in the bridge structure, cracks, cracks, stains, as well as defects in the pavement covering the same. They were photographed and properly characterized. The technique and methodology for registering and organizing the subsidies collected are of fundamental importance for their use in formulating the diagnosis (Lichtenstein, 1986; Arivabene, 2015).

The process of understanding a pathological problem can be described as generating hypotheses or models and testing them. In other words, based on certain fundamental data, the professional elaborates hypotheses for assessing the situation and compares these models to the general symptom picture and the knowledge he has about the pathology, according to Lichtenstein (1986). Following this reasoning, after collecting and interpreting the data, they will be analyzed in detail and the solution that has the best performance in terms of technical, economic, and environmental aspects will be proposed.

\section{Results and Discussion}

\subsection{Pathologies found}

In Figure 3, the main pathologies diagnosed in the concrete structure under study are presented. The degradation and segregation of the concrete are visible, there is a concentration of coarse aggregates at the bottom of the slab and the support, and the reinforcement of the structure and the effects of its corrosion are observed. In addition, the surface elements of the structure show clear signs of moisture and infiltration, probably caused by some failure in the drainage elements. There are signs of the leaching process and the presence of salt deposits (efflorescences). Such pathological manifestations have probable origins thanks to the inadequate design, the execution of the work, or the quality of the materials used, possibly such problems are aggravated by the lack of periodic maintenance and age of the work, according to Helene (1992).

Figure 3. Pathological manifestations found in the analyzed bridge.

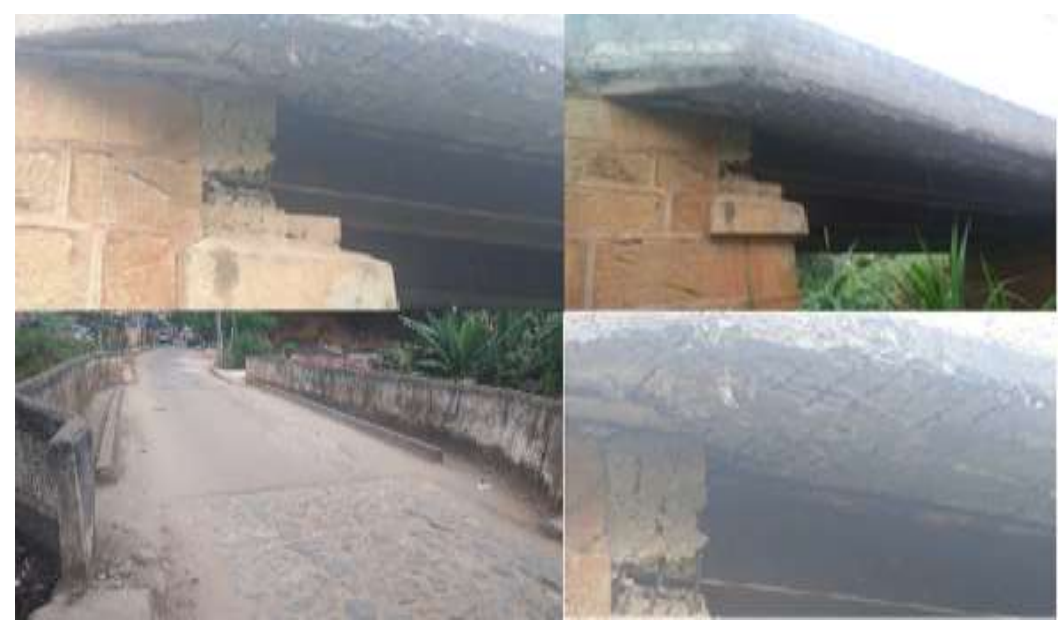

Source: Authors (2021).

It is important to observe, in Figure 3, the pathologies described above, such as the loss of concrete cover, leaching process and accumulation of salts, believed to have originated since its execution, which occurred incorrectly.

The breakdown of the concrete can be verified in the structure tray and characterized by the deterioration of the concrete by fragmentation of its parts, caused, in the great majority, by the expansion as a result of the oxidation or expansion of the reinforcements, by the increase of the volume of concrete, when it absorbs water, and also due to insufficient openings in the expansion joints, causing unforeseen tangential tensions. It can also occur due to the action of structural movements and 
shocks in the structure (Bastos \& Miranda, 2017; Laner, 2001). The concentration of gravel in the lower faces may indicate a process of corrosion of the concrete by physical-chemical processes, an error in the execution phase, especially in the casting and curing part of the concrete, or in the design part (insufficient coverage).

The degradation and segregation process of the concrete in the structure under analysis can be caused by the poor quality of the material and the inadequate production, casting, or curing of the concrete. Failures and obstructions in the drainage devices can generate an accumulation of local water and/or increase in moisture in the concrete, intensifying the corrosive processes (Silva, 2017).

The corrosion of the reinforcement verified in the construction can be justified by a possible porosity of the concrete, small cracks in the material, or even a deficiency in the covering, exposing, partially or totally, sections of the steel. Therefore, such factors may have allowed the frames to be affected by aggressive elements over the years, thus causing their oxidation. In addition, the oxidized part can increase its volume by up to eight times and the force of the expansion expels the concrete from the covering, as can be seen in Figure 1, totally exposing the reinforcement to the aggressive action of the medium. The continuity of this phenomenon leads to the destruction of the framework (Vitório, 2003; Barbosa et al., 2012).

In Figure 4, it is possible to see the pathology of fissure and efflorescence. Cracking is characteristic of the event in which the resistive stress of the part of the structure receives more stresses than it can withstand. Cracks, even those of very small dimensions, facilitate the continuous deterioration of concrete by corrosion processes, which can compromise the structure. In addition, they may indicate the presence of stresses not foreseen in the artwork or even the loss of the structure's resistive capacity. Efflorescence, according to Neville (1997), is more likely to occur when cold and rainy weather is followed by a dry and hot period, which is recurrent in the city of Teófilo Otoni, given its climatic variations. It is also possible to identify, in Figure 4, whitish spots, which possibly are from salt deposits; and, on the underside of the slab, there appear to be stalactite-type deposits at some points. A search for records about the work, through design, documents, photos of its construction, or dialogue with residents, allows a more precise determination of the causes of the pathological manifestations found and can help in the formulation of appropriate maintenance interventions.

Figure 4. Pathological manifestations found in the analyzed bridge.

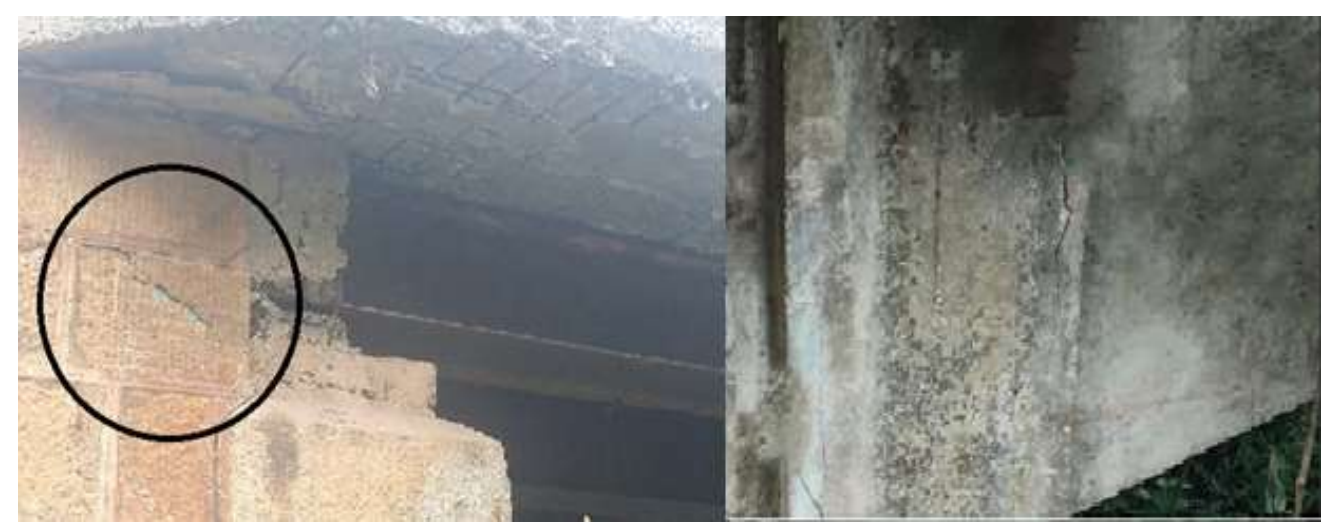

Source: Authors (2021).

Therefore, as already discussed above, Figure 4 illustrates the fissure and efflorescence failures in the studied bridge. It is important to note that these pathologies found, even on a small scale, can significantly compromise the useful life of the artwork, as well as its safety. 


\subsection{Restoration of the structure}

For the realization of a road bridge restoration project, as the structure under study, it is of fundamental importance to know the stability conditions of the original works, to allow the best possible choice of the methods that will be adopted to guarantee the conditions of safety and functionality of the structure (Bastos \& Miranda, 2017). For this, it is essential to carry out a qualified inspection of the structure. Access to the original project and the documented maintenance routine provides important tools for the correct assessment of pathologies and the proposition of interventions.

In this context, it was found that the cracks may be due to errors in the design of structural elements, or else due to the lack of details of the project to guide the execution. Thus, as structural damage was noted in the bridge elements, the cracks found can be considered active with a small opening, assuming the worst-case scenario. The precise characterization of the active character of the fissure is made possible by monitoring its evolution over time. A repair intervention by injection of epoxy resin is proposed; injections must be made through traps spaced one and a half times from the depth of each fissure (Pereira et al., 2010).

As the manifestation of efflorescence in the structure is found in a humid place, with signs of infiltration in the areas adjacent to the salt deposit, epoxy-based paints can be used to solve the problem. It is a product with excellent resistance to chemical agents, water and atmospheric humidity, characteristics necessary for the pathology and structure in question (Pereira et al., 2010).

The degradation of the structure may be related to corrosion of the reinforcement since it is known that this process has a physical, chemical, or electrochemical origin; the last two being the most important and generically called corrosion. Thus, the first procedure in the recovery of this pathology is the removal of corrosion from the reinforcement. However, to have access to the entire damaged area of the reinforcement, it is necessary to assess the need to shore up the area to be recovered and carry out the scarification of the concrete in this location. In addition, as there was no decrease of about $10 \%$ in the section area, it will not be necessary to add more steel bars as a structural reinforcement. However, anti-corrosion protection (such as anti-corrosion paints in civil construction) must be applied to reinforcements that have been exposed and have undergone oxidation (Zamodzki et al., 2019).

The next step in the intervention about the concrete disintegration is the evaluation of the resistant section of the concrete that remained after cleaning and scarifying the disintegrated portion of the support. Such an evaluation will allow the adoption of different solutions for each case, which may or may not require shoring and range from the occasional addition of coating mortar, for the simplest cases, to the adoption of ways to redo the concreting of the section a be recovered. Due to the state of disintegration of the analyzed bridge, it is proposed to use forms for concreting and correcting the pathology in an efficient and architecturally harmonious way to the original structure, according to Villanueva (2015).

Finally, the cases of infiltration in the work of art indicate the accumulation of moisture in some points of the structure. Such pathology can originate from several types of errors, such as the lack of maintenance and consequent obstruction of the drainage elements, as well as design and/or execution errors, which do not allow the ideal drainage of rainwater in the mesostructure. Regarding restoration interventions, the bridge inspection stage provides evidence of the need for reinforcement and expansion of drainage devices, as well as the possible correction of the slope of the structure necessary for the correct flow of water. Structural analyzes of the possible effects of overload or structural load relief should be taken into account to assess the best intervention. However, it is believed that, for the bridge in question, maintenance operations may be sufficient to correct the infiltration pathology. 


\section{Conclusion}

When analyzing the results, it is evident that the restorations and the consequent correction of the pathologies of the bridge are fundamental, as they guarantee safety, functionality, and, therefore, the longer useful life of the bridge.

As has been presented, several causes cause this structure to have problems, some of which probably originated in the design and execution phases. It is important to take some precautions, such as guaranteeing the quality of the concreting, so that it does not have great porosity, for example, which in the future may cause pathologies, such as the breakdown of concrete found in the studied bridge.

Therefore, there is a clear need for restoration interventions on the bridge located at João Lopes da Silva Street, in the municipality of Teófilo Otoni, to improve the structure and correct pathologies that can cause disastrous consequences, if not repaired, in their rupture.

Thus, there is a great need to search for quality in civil construction to avoid these types of unwanted occurrences. The more qualified the phases of design, execution, and their inspection and maintenance routines are, the less costly the actions of restoration and recovery of the structure will be in the future, avoiding socioeconomic disturbances for the region where it is located.

It is also recommended that Teófilo Otoni's municipal management periodically carry out corrective and preventive maintenance on all reinforced concrete bridges located in the municipality.

We suggest that the present case study becomes a reference for future works so that the planning of the execution of works is managed with a higher level of quality, always looking for constant improvement. The inspection of all the execution processes is essential, as well as the quality control of the materials used in the works, as these factors may have been determinant for the degradation of the studied structure.

\section{References}

Andrade, C. (1992). Manual para diagnóstico de obras deterioradas por corrosão de armaduras. Pini.

Arivabene, A. C. (2015). Patologia em estruturas de concreto armado: estudo de caso. Revista Online Especialize IPOG. 1(10), 5-6.

Barbosa, F. R., Carvalho, J. R., Costa e Silva, A. J., Franco, A. P. G., \& Mota, J. M. F. (2012). Corrosão de armadura em estruturas de concreto armado devido ao ataque de íons cloreto. In $54^{\circ}$ Congresso Brasileiro do Concreto. Anais. Maceió.

Bastos, H. C. N., \& de Miranda, M. Z. (2017). Principais patologias em estruturas de concreto de pontes e viadutos: manuseio e manutenção das obras de arte especiais. CONSTRUINDO, 9(3), 93-101.

DNIT — Departamento Nacional de Infraestrutura de Transportes. (2004). 010 — PRO Manual de Inspeção de Pontes Rodoviárias. $2^{\text {a }}$ ed.

DNIT (2004). IPR 744. Manual de Recuperação de Pontes e Viadutos Rodoviários.

Helene, P. R. L., Gerschenstein, M., de Oliveira, P. S. F., \& Guimarães, F. A. (1992). Manual de reparo, reforço e proteção de estruturas de concreto. Pini.

Helene, P. R. L. (1997). Vida útil das estruturas de concreto. In IV Congresso Iberoamericano de Patologia das Construções. Palleti, (1).

Laner, F. J. (2001). Manifestações patológicas nos viadutos, pontes e passarelas do Município de Porto Alegre.

Lichtenstein, N.B. (1986). Patologia das Construções. Escola Politécnica da Universidade de São Paulo — EPUSP. Boletim Técnico, 06, 86.

LÜDKE, M. A. (2013). MEDA de. Pesquisa em educação: abordagens qualitativas. EPU.

Marchetti, O. (2008). Pontes de concreto armado. Editora Blucher São Paulo.

Milani, C. J, \& Kripka, M. (2009). Subsídios para o diagnóstico de pontes rodoviárias. Engenharia, ANÁLISE, 15, 10.

Neville, A. M. (1997). Propriedades do concreto. Pini. (2a ed.),

Pereira, A. S., Shitsuka, D. M., Parreira, F. J., \& Shitsuka, R. (2018). Metodologia da pesquisa científica.[e-book]. Santa Maria. Ed (pp. 3-9). UAB/NTE/UFSM. Disponível em: https://repositorio. ufsm. br/bitstream/handle/1/15824/Lic_Computacao_Metodologia-Pesquisa-Cientifica. pdf. 
Research, Society and Development, v. 10, n. 6, e21810615767, 2021

(CC BY 4.0) | ISSN 2525-3409 | DOI: http://dx.doi.org/10.33448/rsd-v10i6.15767

Pereira, J. L. M. B., Miranda, M. L. B., Fainstein, A., Aurélio, L. C., Carvalho, C. L., \& Rosa, C. L. M. (2010). Manual de Recuperação de Pontes e Viadutos Rodoviários. DNIT, Rio de Janeiro.

Pfeil, W. (1979). Pontes em concreto armado: elementos de projetos, solicitações, dimensionamento. Livros Técnicos e Científicos.

Da Silva, J. C., \& dos Santos, B. (2017). Patologia em pontes - estudo de caso em patologias da ponte Pedro Ivo Campos e orientação de reforma. Engenharia Civil - Pedra Branca.

Souza, V. C. M., \& Ripper, T. (1998). Patologia, recuperação e reforço de estruturas de concreto. Pini.

Vasconcelos, F. (2018). Análise das manifestações patológicas em pontes de concreto armado: Estudo de Caso.

Villanueva, M. M. (2015). A importância da manutenção preventiva para o bom desempenho da edificação. Trabalho de Conclusão de Curso para obtenção do grau de Engenheira Civil. Universidade Federal do Rio de Janeiro.

Vitório, A. (2003). Fundamentos da patologia das estruturas nas perícias de engenharia. Recife: Instituto Pernambucano de Avaliações e Perícias de Engenharia.

Zamodzki, C. G. S., Benetti, H. A. P., Dias, G. L., \& Sabbi, V. (2019). Diagnóstico de manifestações patológicas para recuperação de ponte de concreto armado. Revista Técnico-Científica, (21). 